\title{
Institutional difference and outward FDI: Evidence from China
}

\author{
Chengchun $\mathrm{Li}^{1, *}$, Yun Luo ${ }^{2}$, Glauco De Vita ${ }^{3}$ \\ ${ }^{1}$ Business School, Changzhou University, Gehu Middle Road, Changzhou, 213164, China. Tel.: \\ +86 13174051782. E-mail: lcc@cczu.edu.cn * Corresponding author. \\ ${ }^{2}$ Centre for Business in Society, Coventry University, Priory Street, Coventry CV1 5FB, UK. \\ Tel.: +44(0)2476887688. E-mail: yun.luo@coventry.ac.uk \\ ${ }^{3}$ Centre for Business in Society, Coventry University, Priory Street, Coventry CV1 5FB, UK. Tel.: \\ +44(0)2476887688. E-mail: glauco.devita@coventry.ac.uk
}

\section{Accepted by Empirical Economics on 31 August 2018}

[DOI : 10.1007/s00181-018-1564-y EMEC-D-18-00255R2]

\begin{abstract}
This paper investigates the impact of institutional difference on China's outward foreign direct investment (OFDI) through a gravity model. Our estimations are based on a large panel of 150 countries over the period 2003-2015. The results show that the institutional differences of government effectiveness and control of corruption between China and a host country have a statistically significant negative effect on China's OFDI. In addition, our empirical evidence suggests that the 'One Belt One Road' policy does not have the expected positive effect on China's OFDI. Consistent results are obtained from a set of robustness tests. Our findings provide a reasonable guideline for countries aiming to attract Chinese OFDI or seeking factors to boost it.
\end{abstract}

JEL: F18; F21; O43

Keywords: Institutional difference; Outward foreign direct investment; Gravity model; China 


\section{Introduction}

Although much empirical work has focused on understanding the determinants of China's outward Foreign Direct Investment (OFDI), the influence on OFDI of the institutional contexts both at home (China) and in host countries, has received considerably less attention. China's OFDI has increased dramatically over the past two decades. The Chinese nonfinancial OFDI increased from $\$ 5.5$ billion in 2004 to $\$ 181.2$ billion in 2016, rising by approximately 33 times (Statistical Bulletin of China's Outward Foreign Direct Investment, 2015). Such an impressive growth of OFDI from China might be due to the government policy support and the rapid growth of Chinese companies. For example, the Chinese government has been enthusiastically encouraging its "One Belt One Road" strategy ${ }^{1}$ since 2013, to export China's enormous manufacturing output and encourage Chinese companies to expand their business overseas.

The aim of this paper is to empirically investigate the determinants of China's OFDI with a focus on the impact of institutional distance on OFDI, using a comprehensive dataset estimated through a gravity model. The standard gravity model is based on the notion that the magnitude of bilateral trade flows can be explained by the economic mass of host and home countries and the geographic distance between them (Abbott and De Vita, 2011; Deardorff, 2011). The model has been further extended to accommodate the concept of 'distance' in terms of productivity, institution, and culture, among others. Thus, according to the extended

\footnotetext{
1 "One Belt One Road" lunched by president Xi Jinping in 2013, is an export oriented strategy aimed at connecting China with its neighbours in Asia, Europe and Africa. The goal of this strategy, as stated by the National Development and Reform Commission (2015), is about "promoting orderly and free flow of economic factors, highly efficient allocation of resources and deep integration of markets; encouraging the countries along the Belt and Road to achieve economic policy coordination and carry out broader and more in-depth regional cooperation of higher standards; and jointly creating an open, inclusive and balanced regional economic cooperation architecture that benefits all."
} 
gravity model, we would expect that greater institutional distance is an important determinant of FDI activity.

At the theoretical level, several propositions exist in the literature with regard to the importance of institutional distance on FDI. Seyoum (2009) suggests that multinational enterprises (MNEs) are under dual pressures from both home and host institutional environments and the selection of entering a similar market can reduce the uncertainty inherent in foreign market entry. In addition, MNEs have to change their business strategies to meet the requirements of local institutions when entering foreign markets. Based on the 'familiarity bias' perspective, in general, MNEs prefer to invest in host countries with a similar institutional or cultural environment. MNEs from countries with strong institutional quality are less likely to invest in countries with weaker institutional quality and vice versa. The institutional distance between host and home countries leads MNEs to pay extra costs on adjusting their strategies to adapt to the institutional environment in host countries. Such adaptation costs lower MNEs' profitability thus reducing their investment motivation (Cezar and Escobar, 2015). As a consequence, the higher the institutional distance between host and home country, the lower the amount of OFDI to be expected.

Many studies have explored the determinants of Chinese OFDI (Buckley et al., 2007; Cheung and Qian, 2009; Zhang and Daly, 2011; Kolstad and Wiig, 2012; Ramasamy et al., 2012; Wang et al., 2012; Buckley et al., 2016; Che et al., 2017), finding that labour costs, market size, natural resources as well as institutional factors significantly affect China's OFDI. Yet, empirical knowledge as to how home-host country institutional differences drive OFDI from China remains unclear. Similarly, although the literature emphasises that host country institutional factors (Buckley et al., 2007; Kolstad and Wiig, 2012) or home country institutional characteristics (Wang et al., 2012) matter for Chinese OFDI, the impact of institutional distance between host country and China on Chinese OFDI is largely untested. 
The two notable exceptions are Buckley et al. (2016) and Che et al. (2017). Buckley et al. (2016) include institutional factors for both China and host countries and investigate the impact of institutional factors on cross-border merger and acquisitions in China. Che et al. (2017) investigate the institutional distance nexus of Foreign Invested Enterprises (FIEs) as a proxy of inward FDI in China. However, neither of these studies attempted to examine the impact of institutional distance on the volume of OFDI from China, and at a macro-level.

The present study contributes to this literature in two ways. First, we emphasise the importance of institutional differences rather than the level of institutional quality per se, as we find a positive and significant impact of institutional differences and an insignificant effect of institutional quality. Second, we examine the relationship between institutional differences and OFDI using different dimensions of institutional indicators instead of using an aggregate institutional index as commonly employed in prior studies (e.g. Bekaert et al., 2011; Slesman et al., 2015). Findings based on the distinct dimensions of institutional difference allow us to provide more specific guidelines for countries aiming to attract Chinese OFDI or seeking factors to boost it.

To carry out our investigation, we employ a gravity model to analyse the determinants of Chinese OFDI. We find that the institutional differences of government effectiveness and control of corruption have a robust and negative effect on China's OFDI. However, we do not find any robust effect of basic variables (e.g. China's GDP, GDP of host country, geographic distance) used in the standard gravity model. In addition, we also examine the effect of the 'One Belt One Road' policy. Specifically, whether it increases the amount of Chinese OFDI. In contrast to prior studies (Huang, 2016; Du and Zhang 2018) - which suggest that the 'One Belt One Road' initiative encourages Chinese OFDI activities - our results suggest that the 'One Belt One Road' policy, so far, appears to be an obstruction to Chinese OFDI. 
The rest of this paper is structured as follows. Section 2 provides a brief literature review. Section 3 discusses the methodology and data. Section 4 presents the empirical analysis. Section 5 reports the robustness tests and highlights some policy implications. Section 6 concludes.

\section{Literature Review}

Buckley and Casson (1976) conclude that firms use FDI to replace imperfect external markets or internal shortages in products and knowledge (e.g. exporting and licensing), and until the costs of further internalisation outweigh the benefits. Dunning's eclectic paradigm concludes that there are three primary motivations for FDI (Dunning, 1988): foreign-marketseeking FDI; efficiency-seeking (cost reduction) FDI; resource-seeking FDI (resourceseeking or strategic- asset-seeking).

There have been many empirical studies investigating the determinants of FDI that have, when taken collectively, provided mixed results depending on the choice of model specification, sample and empirical method employed (e.g. Brada et al., 2006; Brada et al., 2012; Blonigen and Piger, 2014; Bojnec and Fertő 2017; Bojnec and Fertő 2018; Li et al., 2017). Using data for seven transition economies of Central Europe over the period 19932001, Brada et al. (2006) find that FDI inflows are not affected by factors such as conflict and political instability. Brada et al. (2012) analyse the effect of corruption on FDI inflows in six East European transition economies over the period 2000-2003 and suggest that there is a negative relationship between the level of corruption in host country and the likelihood of MNEs locating in that country. Also, they find a U-shape relationship between the level of corruption and the amount of FDI inflows. Blonigen and Piger (2014) primarily focus on the OECD countries during the period 1990-2000 and use Bayesian statistical techniques to select a set of candidate variables most likely to determine FDI inflows. They point out that 
factors including traditional gravity variables, cultural distance, relative labour endowments and trade agreements are likely to have explanatory power in FDI determination while they find little evidence in favour of factors such as multilateral trade openness, most business costs, and host country institutions in attracting FDI. Bojnec and Fertő (2017) investigate the impact of globalisation and corruption on OFDI for 22 OECD countries and suggest that FDI is more likely in corruption-free and economically globalised OECD host countries. Similarly, Bojnec and Fertő (2018) find that OFDI is driven positively by globalisation, a corruption-free environment, cross-country similarity, and money laundering in the host country, but negatively by the existence of tax havens in host countries. Li et al. (2017), using economic sectoral data for 128 developing countries over the period 2003-2012, find evidence that control of corruption has a positive and significant effect on FDI inflows to the primary and secondary sectors of the host country and government stability has a positive and significant association with FDI inflows to the tertiary sector, while civil war has a negative impact on FDI inflows to the secondary and tertiary sectors.

\subsection{Determinants of OFDI in China}

Since FDI theory is mostly developed on the basis of the investment experience of industrialised countries, it is widely recognised that it requires a special application to the Chinese context (see, e.g. Buckley et al., 2007). Capital market imperfections may promote Chinese OFDI to explore capital for lower borrowing rates than domestic conventional financing. Moreover, Chinese MNEs have ownership advantages that allow them to operate more effectively than local firms and industrialised countries' MNEs. These ownership advantages may be due to China's business group which is defined as being bound by formal or informal ties, benefiting from inward linkages and institutional support via economising the use of capital and resources for internationalisation (Yiu, 2011). Additionally, the 
institutional factors for host and home country could also determine the ability and the willingness of domestic firms to invest abroad.

There are many empirical studies on the determinants of China's OFDI. Buckley et al. (2007) find that Chinese OFDI is associated with high levels of political risk, cultural proximity, and market size in host countries from 1984 to 2001; and with host natural resources and endowments from 1992 to 2001. Similarly, Cheung and Qian (2009) and Zhang and Daly (2011) find that China's OFDI is positively related to international trade, market size, and resource-seeking (endowments of natural resources). Few, relatively recent studies, focus on Chinese investment abroad by considering institutional factors. Seyoum and Lin (2015) find that government incentive packages of host countries affect Chinese OFDI in Ethiopia. Wang et al. (2012) suggest that the government support was a critical factor in the observed trend of OFDI by Chinese firms. Kolstad and Wiig (2012) find that countries with a large market, rich in natural resources and poor institutions appear to be attractive to Chinese OFDI. Previous literature suggests that the motivations of Chinese OFDI are seeking market and natural resources such as coal and iron ore, among others. However, the impact of institutional factors is still inconclusive, the possible reason might be that these studies do not include a measure of institutional factors, the 'institutional distance' between host and home countries.

\subsection{Institutional differences and FDI}

The early institutional-FDI theory focuses on home country and provides two opposite views on the relationship between home country institutional factors and FDI. Buckley et al. (2007) indicate that the will and ability of firms to invest abroad are facilitated or constrained by institutional factors. For example, supportive policies introduced by home country governments will encourage firms to engage in overseas expansion. On the other hand, Luo et 
al. (2010) suggest that a poor institutional environment in the home country, such as a weak legal system, corruption, regulatory uncertainty, and limited intellectual property rights protection, may increase firms to move abroad in pursuit of more efficient institutions. Nevertheless, though home country institutional factors would have some impact on FDI when entering foreign markets, firms should follow the local institutional requirements, FDI would also be influenced by host country institutional factors. A recent study by Cezar and Escobar (2015) provides a theoretical explanation; MNEs face fixed adaptation costs in adjusting to the institutional environments from home country to host country, thus suggesting that greater institutional distance would increase adaptation costs, lower firm profits, and reduce the number of firms that undertake FDI. They examine empirically the impact of institutional distance on outward and inward FDI in 31 OECD countries and the results confirm their theoretical postulation. However, they use principal component analysis to construct only one index as a proxy of overall institutional distance. Chanegriha et al. (2017) investigate the determinants of FDI in 168 countries over the period 1970-2006 using extreme bounds analysis and suggest that institutional quality and quality of governance matter. ${ }^{2}$ There is a strand of cross-country studies that shows that institutional distance between host and home country in terms of corruption level (Habib and Zurawicki, 2002),

\footnotetext{
${ }^{2}$ Extreme Bounds Analysis (EBA) constitutes a relatively useful way of dealing with the problem of selecting variables for an empirical model in a situation where there are conflicting or inconclusive suggestions in the literature by establishing which of these variables are robust or fragile determinants. However, our interest in this paper does not centre on conducting a sensitivity analysis to determine which among the long list of potential economic, geographical and political variables suggested in the literature review are robust or fragile determinants of FDI but rather, on the impact of institutional difference on China's OFDI through a gravity model which, by itself, provides a priori expectations as to which control variables should be included. As such, we do not concern ourselves with robustness tests using EBA. Moreover, as pointed out by Temple (2000), robustness of a variable (in the sense that its significance is not depending on the choice of conditioning variables) is neither a necessary nor a sufficient condition for an interesting finding and, especially if causality is indirect (e.g. a variable affects investment or human capital), EBA robustness should be interpreted extremely carefully. In addition, a robust variable may not be very interesting as robustness is defined in terms of significance of coefficients. A robust variable may therefore be of little quantitative importance.
} 
legal rules (Guiso et al., 2009), and bureaucracy and legal constraints (Benassy-Quere et al., 2007), reduces bilateral FDI flows.

Regarding the empirical FDI studies in the China context, Buckley et al. (2016) investigate location strategies of Chinese cross-border merger and acquisitions (M\&As) during the period 1985-2011 across 150 economies and find that both institutional factors in China and in the host countries are important location determinants, and that the amount of investment of Chinese M\&As is positively related to poor host country institutional factors. Che et al. (2017) focus on the impact of institutional distance between host and home country on inward FDI in China and find that Foreign Invested Enterprises (FIEs) from countries with better institutions than China are more sensitive to institutional difference.

\section{Data and Methodology}

The basis of our empirical model is the FDI gravity model that is widely used in the economics and international business literature to explain country-level trade and FDI flows (Zwinkels and Beugelsdijk, 2010). Newton's law of universal gravitation states that the gravitational forces between two objects depend on their mass and distance. In the context of FDI, larger economies (as measured by GDP) are expected to have greater FDI activity, while greater geographic distance leads to less FDI activity. Blonigen and Piger (2014) find that the main gravity variables - GDP and geographic distance - are the most robustly significant determinants of FDI flows. More specifically, a country with larger economic size is expected to have greater demand and production potential for products as an importing and an exporting country. These results are fairly consistent across FDI studies that use the gravity framework (see, for example, Zwinkels and Beugelsdijk, 2010; Fratianni et al., 2011; Abbott et al., 2012) also using alternative estimation methods, such as Cushman and De Vita (2017) who employ propensity score matching rather than regression analysis. But we should 
emphasise that whilst GDP, as a proxy for economic size, has often been found to be a significant determinant of FDI, many studies on the causal link between FDI and economic growth have also shown that FDI has a significant impact on growth. For example, Hansen and Rand (2006), who specifically test for Granger causal relationships between FDI and GDP in a sample of 31 developing countries covering 31 years using estimators for heterogeneous panel data, find bi-directional causality between the FDI-to-GDP ratio and the level of GDP. They also find that FDI has a lasting impact on GDP, and in a model for GDP and FDI as a fraction of gross capital formation, they also find long-run effects from FDI to GDP. They take these results as evidence in favour of the hypothesis that FDI has an impact on GDP via knowledge transfers and adoption of new technology.

Our paper focuses on the impact of institutional distance on OFDI, thus we expand the simple gravity equation using distance variables, namely, institutional distance. Ghemawat (2001) indicates that "distance" occurs not only in geographic terms but also in cultural, administrative and economic terms. Therefore, we include six measures of institutional quality distance between China and host countries, namely, government effectiveness distance, political stability distance, regulatory quality distance, voice and accountability distance, rule of law distance, and control of corruption distance. Finally, besides gravity-related factors, we also include the exchange rate of the host country as a control variable.

\subsection{Empirical Model}

We examine the relationship between OFDI and its determinants using Dummy Variable Least Squares (DVLS) estimation ${ }^{3}$ including dummy variables representing each year and

\footnotetext{
${ }^{3}$ In order to tackle the potential cross-section correlation problem, we apply fixed effects generalised least squares (FEGLS) for robustness to check the consistency of the relationship between institutional differences and OFDI.
} 
home countries. Feenstra (2015) indicates that the fixed effects model produces the most consistent and reliable results to estimate gravity of trade flows. The time-invariant variable (such as distance) is included in our model, therefore, Dummy Variable Least Squares (DVLS) estimation is appropriate and it works in the same way as the fixed effects model. Our empirical model for OFDI is specified as follows:

$$
\begin{aligned}
\ln \left(\text { OFDI }_{j t}\right)= & \alpha_{0}+\alpha_{1} \ln \left(\text { GDP }_{j t}\right)+\alpha_{1} \ln \left(\text { GDPCHN }_{t}\right)+\alpha_{1} \ln \left(\text { Distance }_{j}\right) \\
& +\alpha_{1} \ln \left(\text { Exchange }_{j t}\right)+\alpha_{1} \ln \left(\text { Diff_Institutions }_{j t}\right)+D_{j}+D_{t}+\varepsilon_{i t}
\end{aligned}
$$

where $\ln \left(O F D I_{j t}\right)$ is the logarithm of the amount of OFDI flows from China to the recipient or host country $j$ at time $t$; GDP and GDPCHN represent the economic size of the host country and China, respectively; Distance $_{j}$ reflects geographic distance between country $j$ and China; Exchange stands for the exchange rate between China and the host country; and Diff_Institutions refers to a set of institutional variables to measure institutional differences (or distances) between the host country and China. Also, we control for the country and time fixed effects by including two sets of dummy variables, $D_{j}$ and $D_{t}$. To mitigate the potential reverse causality problem, we lag all explanatory variables by one year. Also, it is plausible that there is a time effect of some explanatory variables such as GDP, institutional differences in the present year do not have an immediate influence on OFDI yet may have an effect on OFDI in a subsequent year.

\subsection{Data and Sample}

Our sample consists of a panel of 150 countries and covers the period from 2003 to 2015 . The data used in this study were obtained from several sources. OFDI data are collected from the Statistical Bulletin of China's Outward Foreign Direct Investment (2015, 2012, 2010). Data on GDP and the exchange rate are drawn from World Development Indicators. Our institutional quality variables are obtained from Worldwide Governance Indicators (WGI). 
Data on geographic distance is taken from Mayer and Zignago (2011) and is measured in kilometres between the principal cities of countries weighted by population size in order to account for the uneven spread of population across a country.

Table 1 reports the descriptive statistics. The average values of institutions of China and host countries display considerable distance. China has worse institutional qualities (apart from the government effectiveness) than the average level of the host countries. Table 2 provides pairwise correlations between explanatory variables. Apart from correlation among institutional differences, there is no issue of high collinearity ${ }^{4}$.

[Tables 1 and 2 about here]

\section{Empirical Results}

Table 3 reports the estimated results of the determinants of OFDI from China using DVLS. Column 1 shows the results of the baseline model which consider the effects of GDP level of host country, GDP level of China, exchange rate effectiveness of China and distance between China and host country. Again, in order to tackle the potential issue of reverse causality and consider the time effect of each determinant, we lag each variable (except distance) by one year. GDP level of host country, distance between China and host country and exchange rate have a negative and significant effect on OFDI from China at the 5\% level of statistical significance, whereas GDP level of China exerts a positive and significant effect on OFDI at the $1 \%$ level.

In columns 2-7, the effect of the institutional differences between China and host country is controlled for. As mentioned earlier, to avoid the collinearity problem among

\footnotetext{
${ }^{4}$ At this stage, we do not strictly follow the variable choices from the gravity model due to the high correlation among GDP, GDP per capita, population and exchange rate. We remove variables of GDP per capita and population, and then there is no multicollinearity problem. Also, we only include one variable of institutional difference in one regression to avoid the multicollinearity problem.
} 
variables of institutional difference, we include each variable separately. The results suggest that the difference of government effectiveness and the difference of control of corruption negatively and significantly correlate to OFDI. The rest of the indicators of institutional difference, however, do not have any significant impact on OFDI. The results of the control variables (used in the baseline model) in columns 2-7 are broadly similar to the results shown in column 1. The findings of Table 3 suggest that better economic performance of China (higher output level and stronger currency) leads to more OFDI from China. However, longer distance from China to host country reduces the level of OFDI. Interestingly, the negative significance of $\ln (G D P)(-1)$ indicates that a higher level of host country economic output lowers the level of OFDI from China. This may be because of the OFDI policies by China's central government which has insisted on locating a large amount of investment in Africa and developing countries in Asia. For example, the 'One Belt One Road' enforces the basic OFDI policy direction by aiming to create a deeper connection with 70 developing countries by increasing the volume of OFDI and strengthening the cooperation for investment with those countries.

[Table 3 about here]

In order to provide potent evidence for the importance of institutional differences rather than the level of institutions, we test the effect of institutional quality of both home and host countries by comparing it to the institutional difference between home and host countries to see which one matters most. Similarly, we control for the effect of institutional quality by introducing single institutional quality in one regression for averting the collinearity problem. The estimated results of Table 4 suggest that neither the home country nor the host country institutional quality has a significant effect on OFDI from China. Compared to Table 3, the results indicate that the effect of institutional quality does not matter but institutional difference does. 
[Table 4 about here]

\section{Robustness Analysis and Policy Implications}

In order to check the consistency of the results, we conduct a set of robustness tests using the same set of regressors used in Table 3, our main regression model. First, we apply Fixed Effects Generalised Least Squares (FEGLS) to address the potential cross-section correlation issue. The results are reported in Table 5. It is clear that the GDP level of China exerts a negative and significant effect on OFDI, whereas other baseline control variables appear not to be robust since they lose significance compared to their respective coefficients in Table 3 . In terms of institutional differences, the results are essentially unchanged. Diff_Government(1) and Diff_Corruption (-1) have a negative and significant effect on OFDI at the $1 \%$ level.

[Table 5 about here]

Second, we consider the importance of the 'One Belt One Road' policy (China's aim to prioritise the cooperation with 70 developing countries) using the GLS estimator with a difference-in-difference (DID) treatment ${ }^{5}$. These results, reported in Table 6 , suggest that the effect of the institutional difference of government effectiveness and control of corruption show a consistent pattern. In terms of baseline control variables, only distance has a significant impact on the dependent variable. In addition, the DID interaction shows a negative effect on OFDI, indicating that the 'One Belt One Road' policy, in fact, reduced the motivation of OFDI from China. Although the policy aimed at stimulating Chinese FDI to 70 developing countries, our data unveils a downward influence, at least, in the short-run. The results may differ over a longer time span but we only have data up to 2015 . Nevertheless,

\footnotetext{
${ }^{5}$ As the 'One Belt One Road' policy was announced in 2013, we add a time dummy, coded 1, if year $\geq 2013$, and 0 otherwise. We add a country dummy, coded 1 , if the country is in the cooperation list, and 0 otherwise. Then, we construct an interaction term using time and country dummies.
} 
our results would suggest that Chinese investors are influenced more by the difference of the institutional environment between China and the host country than the government intervention.

\section{[Table 6 about here]}

Third, we use Heckman procedures to tackle the potential sample selection bias resulting from the exclusion of countries having no FDI from China. These results, reported in Table 7, suggest that institutional differences, Diff_Government(-1) and Diff_Corruption (1), have a robust negative impact on OFDI. Furthermore, the Mills ratio is significant at the $1 \%$ level, indicating that there is a sample selection bias if we do not control for the Mills ratio.

\section{[Table 7 about here]}

To conclude, institutional differences exert a robust effect since their significance and signs are stable across Table 3 and Tables 5-7. The institutional difference between China and host country determines the willingness of Chinese MNEs to invest. Based on the mean values of institutions from Table 1, we can observe that the mean of China's government effectiveness is higher than the worldwide mean. The gap of government effectiveness can increase the costs of Chinese MNEs investing abroad and lower their efficiency when they encounter bureaucratic administration and investment approval from authorities since host countries' governments, to some extent, tend to impact the volume, scope and direction of OFDI from China. Regarding the difference of control of corruption, although China has made considerable efforts to control the corruption since President Xi started an anticorruption campaign in 2012, China's mean of control of corruption is still lower than the worldwide mean due to various historical reasons. Under such a corrupted environment, Chinese investors were used to spending extra costs on bribery to obtain some advantages for their investment. When Chinese MNEs go abroad and face a more honest and transparent 
environment, they find it difficult to take advantages from political connections and this reduces their investment motivation. In addition, the institutional difference seems to be more important than the 'One Belt One Road' policy. Although the original intention of the government was to support MNEs to make more investment abroad, our data suggest that the effect seems to be going in the opposite direction. According to Amendolagine et al. (2013), the reason might be that the Chinese central government uses OFDI as a political tool to invest in strategic areas and sectors - some Chinese MNEs appear to be forced by Chinese central government to invest abroad.

\section{Conclusion}

In this paper we contribute to the literature by highlighting the importance of institutional difference between home and host countries rather than the level of institutional quality in the home or host country. Using a panel of 150 countries over the period 2003-2015, we examine the separate effect of each institutional difference indicator instead of an aggregated institutional index as employed in prior studies. It is now generally recognised that institutional differences have a robust influence in reducing OFDI from China. More specifically, the institutional differences of government effectiveness and control of corruption have a statistically significant negative effect on OFDI from China. In contrast to prior studies which emphasise that the levels of the institutional quality in the home or host countries are the determinants of FDI, we do not find any significance of home or host countries' institutional quality. Also, we do not find a robust effect of distance or economic performance on OFDI and we do not find any significant effect on the level of institutional quality. In addition, we find that the 'One Belt One Road' policy does not have the expected positive effect on Chinese OFDI. 
One of the most important implications that flows from our findings is that China should keep reducing its corruption level and that host countries should focus on increasing their government effectiveness to close the gap of institutional difference to benefit from a 'win-win' result from Chinese OFDI.

One of the limitations of the present study relates to data availability which precluded us from distinguishing the effects of industrial/sectoral FDI inflows. Li et al. (2017) emphasise that the heterogeneity of FDI inflows to different economic sectors can be determined by distinctive factors. Therefore, it is plausible to infer that Chinese OFDI from different economic sectors also might be influenced by different factors. Further research could investigate the determinants of Chinese OFDI using disaggregated data of FDI outflows.

\section{Compliance with Ethical Standards}

Disclosure of potential conflicts of interest: The authors declare that they have no conflict of interest.

Ethical approval: This article does not contain any studies with human participants or animals performed by any of the authors. 


\section{References}

Abbott, A., Cushman, D. O. \& De Vita, G. (2012). Exchange rate regimes and FDI flows to developing countries. Review of International Economics, 20(1), 95-107.

Abbott, A. \& De Vita, G. (2011). Evidence of the impact of exchange regimes on bilateral FDI flows. Journal of Economic Studies, 38(3), 253-274.

Amendolagine, V., Boly, A., Coniglio, N. D., Prota, F. \& Seric, A. (2013). FDI and local linkages in developing countries: Evidence from Sub-Saharan Africa. World Development, 50, 41-56.

Benassy-Quere, A., Coupet, M. \& Mayer, T. (2007). Institutional determinants of foreign direct investment. World Economy, 30(5), 764-782.

Bekaert, G., Harvey, C. R. \& Lundblad, C. (2011) 'Financial Openness and Productivity'. World Development 39 (1), 1-19

Blonigen, B. A. \& Piger, J. (2014). Determinants of foreign direct investment. Canadian Journal of Economics/Revue canadienne d'économique, 47(3), 775-812.

Bojnec, Š. \& Fertő, I. (2017). Effects of globalization and corruption on the outward FDI in OECD countries. Ekonomicky Casopis, 65(3), 201-219.

Bojnec, Š S. \& Fertő, I. (2018). Globalization and outward foreign direct investment. Emerging Markets Finance and Trade, 54(1), 88-99.

Brada, J. C., Kutan, A. M. \& Yigit, T. M. (2006). The effects of transition and political instability on foreign direct investment inflows. Economics of Transition, 14(4), 649680.

Brada, J. C., Drabek, Z. \& Perez, M. F. (2012). The effect of home-country and host-country corruption on foreign direct investment. Review of Development Economics, 16(4), 640-663.

Buckley, P. J. \& Casson, M. (1976). Future of the multinational enterprise, Springer.

Buckley, P. J., Clegg, L. J., Adam, R. C., Liu, X., Hinrich, V. \& Ping, Z. (2007). The determinants of Chinese outward foreign direct investment. Journal of International Business Studies, 38(4), 499-518.

Buckley, P. J., Yu, P., Liu, Q., Munjal, S. \& Tao, P. (2016). The institutional influence on the location strategies of multinational enterprises from emerging economies: evidence from China's cross-border mergers and acquisitions. Management and Organization Review, 12(3), 425-448. 
Cezar, R. \& Escobar, O. R. (2015). Institutional distance and foreign direct investment. Review of World Economics, 151(4), 713-733.

Chanegriha, M., Stewart, C. \& Tsoukis, C. (2017). Identifying the robust economic, geographical and political determinants of FDI: an Extreme Bounds Analysis. Empirical Economics, 52(2), 759-776.

Che, Y., Du, J., Lu, Y. \& Tao, Z. (2017). Institutional difference and FDI location choice: evidence from China. Available from: https://ideas.repec.org/p/pra/mprapa/77158.html

Cheung, Y.-W. \& Qian, X. (2009). Empirics of china's outward direct investment. Pacific Economic Review, 14(3), 312-341.

Cushman D. O. \& De Vita, G. (2017). Exchange rate regimes and FDI in developing countries: a propensity score matching approach. Journal of International Money and Finance, 77, 143-163.

Deardorff, A. V. (2011). Determinants of bilateral trade: does gravity work in a neoclassical world? Comparative advantage, growth, and the gains from trade and globalization: a festschrift in honor of alan $v$ deardorff. World Scientific.

Du, J. \& Zhang, Y. (2018). Does one belt one road initiative promote chinese overseas direct investment? China Economic Review, 47, 189-205.

Dunning, J. H. (1988). The eclectic paradigm of international production: a restatement and some possible extensions. Journal of International Business Studies, 19(1), 1-31.

Feenstra, R. C. (2015). Advanced international trade: theory and evidence, Princeton University Press.

Fratianni, M. U., Marchionne, F. \& Oh, C. H. (2011). A commentary on the gravity equation in international business research. Multinational Business Review, 19(1), 36-46.

Ghemawat, P. (2001). Distance still matters: the hard reality of global expansion. Harvard Business Review, 79(8), 137-147.

Guiso, L., Sapienza, P. \& Zingales, L. (2009). Cultural biases in economic exchange? The Quarterly Journal of Economics, 124(3), 1095-1131.

Habib, M. \& Zurawicki, L. (2002). Crruption and foreign direct investment. Journal of International Business Studies, 33(2), 291-307.

Hansen, H. \& Rand, J. (2006). On the causal links between FDI and growth in developing countries. World Economy, 29(1), 21-41.

Huang, Y. (2016). Understanding china's belt \& road initiative: Motivation, framework and assessment. China Economic Review, 40, 314-321. 
Kolstad, I. \& Wiig, A. (2012). What determines Chinese outward FDI? Journal of World Business, 47(1), 26-34.

Li, C., Murshed, S. M. \& Tanna, S. (2017). The impact of civil war on foreign direct investment flows to developing countries. The Journal of International Trade \& Economic Development, 26(4), 488-507.

Luo, Y., Xue, Q. \& Han, B. (2010). How emerging market governments promote outward FDI: Experience from China. Journal of World Business, 45(1), 68-79.

Mayer, T. \& Zignago, S. (2011). Notes on CEPII's distances measures: The GeoDist database. Available from: http://www.cepii.fr/CEPII/en/publications/wp/abstract.asp?NoDoc $=3877$

MOFCOM. (2010). Statistical bulletin of China's outward foreign direct investment. Ministry of Commerce Beijing.

MOFCOM. (2012). Statistical bulletin of China's outward foreign direct investment. Ministry of Commerce Beijing.

MOFCOM. (2015). Statistical bulletin of China's outward foreign direct investment. Ministry of Commerce Beijing.

National Development and Reform Commission, Ministry of Fore. (2015). National Development and Reform Commission, Ministry of Foreign Affairs, and Ministry of Commerce, People's Republic of China, Vision and actions on jointly building silk road economic belt and 21st-century maritime silk road. Available from: http://en.ndrc.gov.cn/newsrelease/201503/t20150330 669367.html

Ramasamy, B., Yeung, M. \& Laforet, S. (2012). China's outward foreign direct investment: Location choice and firm ownership. Journal of World Business, 47(1), 17-25.

Seyoum, B. (2009). Formal institutions and foreign direct investment. Thunderbird International Business Review, 51(2), 165-181.

Seyoum, M., \& Lin, J. (2015). Private Chinese investment in Ethiopia: Determinants and location decisions. Journal of International Development, 27(7), 1223-1242.

Slesman, L., Baharumshah, A. Z. \& Wohar, M. E. (2015). Capital inflows and economic growth: Does the role of institutions matter? International Journal of Finance \& Economics, 20(3), 253-275..

Temple, J. (2000). Growth regressions and what the textbooks donet tell you. Bulletin of Economic Research, 52(3), 181-205. 
Wang, C., Hong, J., Kafouros, M. \& Boateng, A. 2012. What drives outward FDI of Chinese firms? Testing the explanatory power of three theoretical frameworks. International Business Review, 21(3), 425-438.

Yiu, D. W. (2011). Multinational advantages of Chinese business groups: A theoretical exploration. Management and Organization Review, 7(2), 249-277.

Zhang, X. \& Daly, K. (2011). The determinants of China's outward foreign direct investment. Emerging Markets Review, 12(4), 389-398.

Zwinkels, R. C. J. \& Beugelsdijk, S. (2010). Gravity equations: Workhorse or Trojan horse in explaining trade and FDI patterns across time and space? International Business Review, 19 (1), 102-115. 
Appendix A. Variable descriptions and data sources

$\begin{array}{ll}\text { Variables } & \text { Description } \\ \text { OFDI } & \text { Annual outward FDI flows from China to the recipient or host } \\ & \text { country }\end{array}$

GDP

GDPCHN China GDP in constant 2010 USD

Distance

Exchange

Democracy

Political

Government

Regulatory

Law

\section{Corruption}

Geographic distance between China and home country (capital) weighted by population size

Home country exchange rate

An index that measures voice and accountability which captures perceptions of the extent to which a country's citizens are able to participate in selecting their government, as well as freedom of expression, freedom of association, and a free media, ranging from approximately -2.5 to 2.5 .

An index that measures political stability which captures perceptions of the likelihood of political instability and/or politically-motivated violence, including terrorism, ranging from approximately -2.5 to 2.5

An index that measures government effectiveness which captures perceptions of the quality of public services, the quality of the civil service and the degree of its independence from political pressures, the quality of policy formulation and implementation, and the credibility of the government's commitment to such policies. Estimate gives the country's score on the aggregate indicator, in units of a standard normal distribution, ranging from approximately -2.5 to 2.5 .

An index that measures regulatory quality which captures perceptions of the ability of the government to formulate and implement sound policies and regulations that permit and promote private sector development, ranging from approximately -2.5 to 2.5 .

An index that measures rule of law which captures perceptions of the extent to which agents have confidence in and abide by the rules of society, and in particular the quality of contract enforcement, property rights, the police, and the courts, as well as the likelihood of crime and violence, ranging from approximately -2.5 to 2.5 .

An index that measures the control of corruption which captures perceptions of the extent to which public power is exercised for private gain, including both petty and grand forms of corruption, as well as "capture" of the state by elites and private interests, ranging from approximately -2.5 to 2.5 .

\section{Source}

Statistical Bulletin of China's

Outward Foreign

Direct Investment

$(2015,2012,2010)$

World

development

indicator

World

development

indicator

Mayer and

Zignago (2011)

World

development

indicator

Worldwide

Governance

Indicators (WGI)

Worldwide

Governance

Indicators (WGI)

Worldwide

Governance

Indicators (WGI)

Worldwide

Governance

Indicators (WGI)

Worldwide

Governance

Indicators (WGI)

Worldwide

Governance

Indicators (WGI) 
Table 1 Summary statistics

\begin{tabular}{|c|c|c|c|c|c|}
\hline & Obs & Mean & S.D. & Min & $\operatorname{Max}$ \\
\hline $\ln ($ OFDI $)$ & 1801 & 9.3642 & 0.2589 & -0.1863 & 11.5253 \\
\hline $\ln ($ GDP) & 2232 & 24.1887 & 2.3255 & 18.7084 & 30.4403 \\
\hline $\ln ($ GDPCHN $)$ & 2366 & 29.3070 & 0.3570 & 28.6993 & 29.8180 \\
\hline In(Distance) & 2249 & 9.0127 & 0.5420 & 7.0246 & 9.8580 \\
\hline ln(Exchange) & 1953 & 3.4230 & 2.7839 & -1.3137 & 22.6288 \\
\hline Democracy & 2265 & -0.0638 & 1.0082 & -2.3134 & 1.8010 \\
\hline Political & 2267 & -0.0785 & 0.9876 & -3.1808 & 1.6881 \\
\hline Government & 2262 & -0.0183 & 1.0072 & -2.1632 & 2.4370 \\
\hline Regulatory & 2262 & -0.0233 & 1.0023 & -2.5296 & 2.2605 \\
\hline Law & 2267 & -0.0530 & 1.0054 & -2.0324 & 2.1003 \\
\hline Corruption & 2263 & -0.0377 & 1.0289 & -1.7728 & 2.4700 \\
\hline DemocracyCHN & 2366 & -1.6316 & 0.0854 & -1.7490 & -1.4625 \\
\hline PoliticalCHN & 2366 & -0.5269 & 0.0636 & -0.6571 & -0.3902 \\
\hline GovernmentCHN & 2366 & 0.0904 & 0.1454 & -0.1200 & 0.4080 \\
\hline RegulatoryCHN & 2366 & -0.2385 & 0.0570 & -0.3334 & -0.1500 \\
\hline LawCHN & 2366 & -0.4941 & 0.0748 & -0.6395 & -0.4071 \\
\hline CorruptionCHN & 2366 & -0.4733 & 0.1022 & -0.6087 & -0.2821 \\
\hline Diff_Democracy & 2265 & 1.6049 & 0.9511 & 0.0012 & 3.3694 \\
\hline Diff_Political & 2267 & 0.9185 & 0.5799 & 0.0002 & 2.7906 \\
\hline Diff_Government & 2262 & 0.8625 & 0.5515 & 0.0000 & 2.5712 \\
\hline Diff_Regulatory & 2262 & 0.8299 & 0.6045 & 0.0000 & 2.5500 \\
\hline Diff_Law & 2267 & 0.8604 & 0.6855 & 0.0011 & 2.6370 \\
\hline Diff_Corruption & 2263 & 0.8444 & 0.7385 & 0.0001 & 3.0357 \\
\hline
\end{tabular}

Note: GDP: GDP level of host country; GDPCHN: GDP level of China. Exchange: Exchange rate effectiveness of China. Government: Government effectiveness of host country. GovernmentCHN:

Government effectiveness of China. Political: Political stability of host country. PoliticalCHN: Political stability of China. Regulatory: Regulatory quality of host country. RegulatoryCHN: Regulatory quality of China. Democracy: Voice and accountability of host country. Democracy: Voice and accountability of China. Law: Rule of law of host country. LawCHN: Rule of law of China. Corruption: Control of corruption of host country. CorruptionCHN: Control of corruption of China. Diff_Government: Difference of government effectiveness between China and host country. Diff_Political: Difference of political stability between China and host country. Diff_Regulatory: Difference of regulatory quality between China and host country. Diff_ Democracy: Difference of voice and accountability between China and host country. Diff_Law: Difference of rule of law between China and host country. Diff_Corruption: Difference of control of corruption between China and host country. 


\begin{tabular}{|c|c|c|c|c|c|c|}
\hline & $\ln ($ OFDI $)$ & $\ln ($ GDP $)$ & $\ln ($ GDPCHN) & $\ln$ (Distance) & In(Exchange) & Diff_Democracy \\
\hline $\ln ($ OFDI $)$ & 1.0000 & & & & & \\
\hline $\ln ($ GDP $)$ & $0.0648 * * *$ & 1.0000 & & & & \\
\hline $\ln ($ GDPCHN) & 0.0192 & $0.0619 * * *$ & 1.0000 & & & \\
\hline $\ln$ (Distance) & $-0.0932 * * *$ & $-0.1974 * * *$ & 0.0000 & 1.0000 & & \\
\hline ln(Exchange) & $-0.0661 * *$ & $-0.1623 * * *$ & 0.0358 & $-0.0578 * *$ & 1.0000 & \\
\hline Diff_Democracy & 0.0138 & $0.2070 * * *$ & 0.0272 & $0.1496 * * *$ & $-0.3506 * * *$ & 1.0000 \\
\hline Diff_Political & 0.0281 & $0.0654 * * *$ & -0.00940 & $-0.1330 * * *$ & $-0.1914 * * *$ & $0.4227 * * *$ \\
\hline Diff_Government & $0.0545^{* *}$ & $0.1418^{* * *}$ & $0.0439 * *$ & $-0.1413 * * *$ & $0.0914 * * *$ & $0.0985 * * *$ \\
\hline Diff_Regulatory & $0.0772 * * *$ & $0.3603 * * *$ & -0.0105 & $-0.1548 * * *$ & $-0.2269 * * *$ & $0.3574 * * *$ \\
\hline Diff_Law & $0.0586^{* *}$ & $0.3483 * * *$ & -0.0329 & $-0.0873 * * *$ & $-0.3359 * * *$ & $0.5909 * * *$ \\
\hline \multirow[t]{2}{*}{ Diff_Corruption } & $0.0623 * * *$ & $0.3539 * * *$ & -0.0124 & $-0.0425 * *$ & $-0.3153^{* * *}$ & $0.5658 * * *$ \\
\hline & Diff_Political & Diff_Government & Diff_Regulatory & Diff_Law & Diff_Corruption & \\
\hline Diff_Government & $0.3499 * * *$ & 1.0000 & & & & \\
\hline Diff_Regulatory & $0.4788 * * *$ & $0.6913 * * *$ & 1.0000 & & & \\
\hline Diff_Law & $0.6252 * * *$ & $0.6065 * * *$ & $0.8160 * * *$ & 1.0000 & & \\
\hline Diff_Corruption & $0.5964 * * *$ & $0.5989 * * *$ & $0.7559 * * *$ & $0.9119 * * *$ & 1.0000 & \\
\hline
\end{tabular}

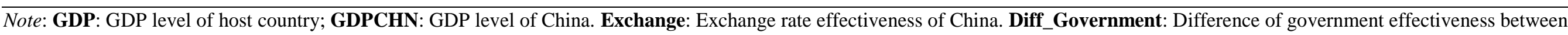

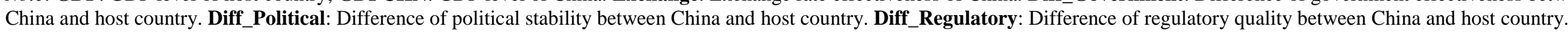

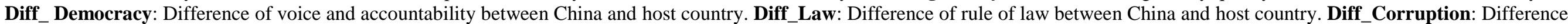

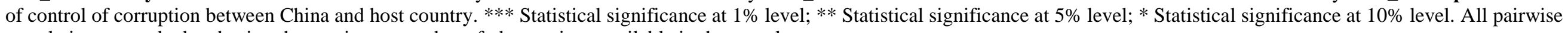
correlations are calculated using the maximum number of observations available in the sample. 
Table 3 Institutional difference and OFDI from China - DVLS estimation

\begin{tabular}{|c|c|c|c|c|c|c|c|}
\hline & 1 & 2 & 3 & 4 & 5 & 6 & 7 \\
\hline $\ln ($ GDP $)(-1)$ & $\begin{array}{c}-0.0293 * * \\
(0.0125)\end{array}$ & $\begin{array}{c}-0.0292 * * \\
(0.0122)\end{array}$ & $\begin{array}{c}-0.0289 * * \\
(0.0125)\end{array}$ & $\begin{array}{c}-0.0291 * * \\
(0.0133)\end{array}$ & $\begin{array}{c}-0.0306 * * \\
(0.0127)\end{array}$ & $\begin{array}{c}-0.0306 * * \\
(0.0126)\end{array}$ & $\begin{array}{c}-0.0292 * * \\
(0.0121)\end{array}$ \\
\hline $\ln (\mathrm{GDPCHN})(-1)$ & $\begin{array}{c}0.0615^{* * * *} \\
(0.0183)\end{array}$ & $\begin{array}{c}0.0684 * * * \\
(0.0196)\end{array}$ & $\begin{array}{c}0.0625 * * * \\
(0.0185)\end{array}$ & $\begin{array}{c}0.0618 * * * \\
(0.0186)\end{array}$ & $\begin{array}{c}0.0629 * * * \\
(0.0184)\end{array}$ & $\begin{array}{c}0.0625 * * * \\
(0.0187)\end{array}$ & $\begin{array}{c}0.0617 * * * \\
(0.0183)\end{array}$ \\
\hline In(Distance) & $\begin{array}{c}-0.1747 * * \\
(0.0680)\end{array}$ & $\begin{array}{c}-0.2550 * * * \\
(0.0767)\end{array}$ & $\begin{array}{c}-0.1689 * * \\
(0.0678)\end{array}$ & $\begin{array}{c}-0.1638 * * \\
(0.0808)\end{array}$ & $\begin{array}{c}-0.1724 * * \\
(0.0731)\end{array}$ & $\begin{array}{c}-0.1832 * * * \\
(0.0692)\end{array}$ & $\begin{array}{c}-0.1885 * * * \\
(0.0688)\end{array}$ \\
\hline In(Exchange)(-1) & $\begin{array}{c}-0.0036 * * \\
(0.0016)\end{array}$ & $\begin{array}{l}-0.0023 \\
(0.0014)\end{array}$ & $\begin{array}{c}-0.0037 * * \\
(0.0016)\end{array}$ & $\begin{array}{c}-0.0036 * * \\
(0.0016)\end{array}$ & $\begin{array}{c}-0.0037 * * \\
(0.0016)\end{array}$ & $\begin{array}{c}-0.0037 * * \\
(0.0016)\end{array}$ & $\begin{array}{c}-0.0038 * * \\
(0.0017)\end{array}$ \\
\hline Diff_Government(-1) & & $\begin{array}{c}-0.0440 * * * \\
(0.0131)\end{array}$ & & & & & \\
\hline Diff_Political(-1) & & & $\begin{array}{c}0.0077 \\
(0.0057)\end{array}$ & & & & \\
\hline Diff_Regulatory(-1) & & & & $\begin{array}{c}0.0063 \\
(0.0142)\end{array}$ & & & \\
\hline Diff_Democracy(-1) & & & & & $\begin{array}{l}-0.0032 \\
(0.0086)\end{array}$ & & \\
\hline Diff_Law(-1) & & & & & & $\begin{array}{l}-0.0014 \\
(0.0122)\end{array}$ & \\
\hline Diff_Corruption(-1) & & & & & & & $\begin{array}{c}-0.0354 * * \\
(0.0156)\end{array}$ \\
\hline constant & $\begin{array}{c}9.7118 * * * \\
(0.7212)\end{array}$ & $\begin{array}{c}10.2414 * * * \\
(0.7005)\end{array}$ & $\begin{array}{c}9.6081 * * * \\
(0.7488)\end{array}$ & $\begin{array}{c}9.5989 * * * \\
(0.8392)\end{array}$ & $\begin{array}{c}9.6812 * * * \\
(0.7245)\end{array}$ & $\begin{array}{c}9.7846 * * * \\
(0.7940)\end{array}$ & $\begin{array}{c}9.8573 * * * \\
(0.7255)\end{array}$ \\
\hline Year dummies & Yes & Yes & Yes & Yes & Yes & Yes & Yes \\
\hline Country dummies & Yes & Yes & Yes & Yes & Yes & Yes & Yes \\
\hline $\mathbf{N}$ & 1394 & 1382 & 1382 & 1382 & 1382 & 1382 & 1382 \\
\hline $\mathbf{R 2}$ & 0.7665 & 0.7691 & 0.7667 & 0.7666 & 0.7666 & 0.7666 & 0.7681 \\
\hline
\end{tabular}

Note: GDP: GDP level of host country; GDPCHN: GDP level of China. Exchange: Exchange rate effectiveness of China. Diff_Government: Difference of government effectiveness between China and host country. Diff_Political: Difference of political stability between China and host country. Diff_Regulatory: Difference of regulatory quality between China and host country. Diff_Democracy: Difference of voice and accountability between China and host country. Diff_Law: Difference of rule of law between China and host country. Diff_Corruption: Difference of control of corruption between China and host country. All explanatory variables except Distance are lagged one time period. GDP, GDPCHN and Exchange are represented in natural logarithms. Dependent variable is outward FDI. Estimation is by Dummy Variables Least Squares (DVLS) with robust standard errors (in parentheses). *** Statistical significance at $1 \%$ level; ** Statistical significance at $5 \%$ level; * Statistical significance at $10 \%$ level. 
Table 4 Institutional quality and OFDI from China - DVLS estimation

\begin{tabular}{|c|c|c|c|c|c|c|}
\hline & 1 & 2 & 3 & 4 & 5 & 6 \\
\hline $\ln ($ GDP $)(-1)$ & $\begin{array}{c}-0.0336 * * \\
(0.0137)\end{array}$ & $\begin{array}{c}-0.0337 * * \\
(0.0134)\end{array}$ & $\begin{array}{c}-0.0366^{* * *} \\
(0.0136)\end{array}$ & $\begin{array}{c}-0.0304 * * \\
(0.0127)\end{array}$ & $\begin{array}{c}-0.0362 * * \\
(0.0141)\end{array}$ & $\begin{array}{c}-0.0261 * * \\
(0.0119)\end{array}$ \\
\hline $\ln (\mathrm{GDPCHN})(-1)$ & $\begin{array}{c}0.0625 * * * \\
(0.0201)\end{array}$ & $\begin{array}{c}0.0611 * * \\
(0.0248)\end{array}$ & $\begin{array}{c}0.0223 \\
(0.3423)\end{array}$ & $\begin{array}{c}0.0698 \\
(0.0644)\end{array}$ & $\begin{array}{c}0.0640 * * * \\
(0.0183)\end{array}$ & $\begin{array}{c}0.0580 * * * \\
(0.0174)\end{array}$ \\
\hline $\ln ($ Distance $)$ & $\begin{array}{c}-0.2135 * * \\
(0.0851)\end{array}$ & $\begin{array}{c}-0.2295 * * * \\
(0.0869)\end{array}$ & $\begin{array}{c}-0.2308 * * * \\
(0.0812)\end{array}$ & $\begin{array}{c}-0.1760 * * \\
(0.0748)\end{array}$ & $\begin{array}{c}-0.2718 * * * \\
(0.1031)\end{array}$ & $\begin{array}{l}-0.1105^{*} \\
(0.0665)\end{array}$ \\
\hline $\ln ($ Exchange $)(-1)$ & $\begin{array}{c}-0.0035 * * \\
(0.0016)\end{array}$ & $\begin{array}{c}-0.0036 * * \\
(0.0016)\end{array}$ & $\begin{array}{c}-0.0038 * * \\
(0.0017)\end{array}$ & $\begin{array}{c}-0.0036 * * \\
(0.0016)\end{array}$ & $\begin{array}{c}-0.0038 * * \\
(0.0016)\end{array}$ & $\begin{array}{c}-0.0035 * * \\
(0.0015)\end{array}$ \\
\hline Government(-1) & $\begin{array}{c}0.0086 \\
(0.0119)\end{array}$ & & & & & \\
\hline GovernmentCHN(-1) & $\begin{array}{c}0.0042 \\
(0.0405)\end{array}$ & & & & & \\
\hline Political(-1) & & $\begin{array}{c}0.0053 \\
(0.0048)\end{array}$ & & & & \\
\hline PoliticalCHN(-1) & & $\begin{array}{c}0.0779 \\
(0.6419)\end{array}$ & & & & \\
\hline Regulatory(-1) & & & $\begin{array}{c}0.0111 \\
(0.0101)\end{array}$ & & & \\
\hline RegulatoryCHN (-1) & & & $\begin{array}{c}0.8964 \\
(7.3174)\end{array}$ & & & \\
\hline Democracy (-1) & & & & $\begin{array}{l}-0.0017 \\
(0.0086)\end{array}$ & & \\
\hline DemocracyCHN(-1) & & & & $\begin{array}{c}0.0728 \\
(0.5533)\end{array}$ & & \\
\hline $\operatorname{Law}(-1)$ & & & & & $\begin{array}{c}0.0178 \\
(0.0122)\end{array}$ & \\
\hline LawCHN(-1) & & & & & $\begin{array}{c}0.0048 \\
(0.1116)\end{array}$ & \\
\hline Corruption(-1) & & & & & & $\begin{array}{l}-0.0152 \\
(0.0100)\end{array}$ \\
\hline CorruptionCHN(-1) & & & & & & $\begin{array}{c}0.0952 \\
(0.6981)\end{array}$ \\
\hline constant & $\begin{array}{c}10.1174 * * * \\
(0.7703)\end{array}$ & $\begin{array}{c}10.3393 * * * \\
(1.2199)\end{array}$ & $\begin{array}{c}11.7932 \\
(12.5370)\end{array}$ & $\begin{array}{c}9.6190 * * * \\
(1.2373)\end{array}$ & $\begin{array}{c}10.6464 * * * \\
(1.0153)\end{array}$ & $\begin{array}{c}9.2106 * * * \\
(0.7933)\end{array}$ \\
\hline Year dummies & Yes & Yes & Yes & Yes & Yes & Yes \\
\hline Country dummies & Yes & Yes & Yes & Yes & Yes & Yes \\
\hline $\begin{array}{l}\mathbf{N} \\
\mathbf{R} 2\end{array}$ & $\begin{array}{c}1382 \\
0.7666\end{array}$ & $\begin{array}{c}1382 \\
0.7667\end{array}$ & $\begin{array}{c}1382 \\
0.7667\end{array}$ & $\begin{array}{c}1382 \\
0.7666\end{array}$ & $\begin{array}{c}1382 \\
0.7668\end{array}$ & $\begin{array}{c}1382 \\
0.7668\end{array}$ \\
\hline
\end{tabular}

Note: GDP: GDP level of host country; GDPCHN: GDP level of China. Exchange: Exchange rate effectiveness of China.

Government: Government effectiveness of host country. GovernmentCHN: Government effectiveness of China. Political:

Political stability of host country. PoliticalCHN: Political stability of China. Regulatory: Regulatory quality of host country.

RegulatoryCHN: Regulatory quality of China. Democracy: Voice and accountability of host country. Democracy: Voice and accountability of China. Law: Rule of law of host country. LawCHN: Rule of law of China. Corruption: Control of corruption of host country. CorruptionCHN: Control of corruption of China. All explanatory variables except Distance are lagged one time period. GDP, GDPCHN and Exchange are represented in natural logarithms. Dependent variable is outward FDI. Estimation is by Dummy Variables Least Squares (DVLS) with robust standard errors (in parentheses). *** Statistical significance at $1 \%$ level; ** Statistical significance at $5 \%$ level; * Statistical significance at $10 \%$ level. 
Table 5 Institutional difference and OFDI from China - FEGLS estimation

\begin{tabular}{|c|c|c|c|c|c|c|c|}
\hline & 1 & 2 & 3 & 4 & 5 & 6 & 7 \\
\hline $\ln ($ GDP)(-1) & $\begin{array}{c}0.0015 \\
(0.0033)\end{array}$ & $\begin{array}{c}0.0050 \\
(0.0038)\end{array}$ & $\begin{array}{c}0.0015 \\
(0.0035)\end{array}$ & $\begin{array}{c}0.0019 \\
(0.0036)\end{array}$ & $\begin{array}{c}0.0010 \\
(0.0035)\end{array}$ & $\begin{array}{c}0.0013 \\
(0.0033)\end{array}$ & $\begin{array}{c}0.0002 \\
(0.0037)\end{array}$ \\
\hline $\ln ($ GDPCHN)(-1) & $\begin{array}{c}0.0116 * * * \\
(0.0027)\end{array}$ & $\begin{array}{c}0.0119 * * * \\
(0.0030)\end{array}$ & $\begin{array}{c}0.0121 * * * \\
(0.0028)\end{array}$ & $\begin{array}{c}0.0116^{* * * *} \\
(0.0028)\end{array}$ & $\begin{array}{c}0.0124 * * * \\
(0.0028)\end{array}$ & $\begin{array}{c}0.0117 * * * \\
(0.0027)\end{array}$ & $\begin{array}{c}0.0132 * * * \\
(0.0027)\end{array}$ \\
\hline $\ln ($ Distance $)$ & $\begin{array}{l}-0.0028 \\
(0.0198)\end{array}$ & $\begin{array}{l}-0.0006 \\
(0.0234)\end{array}$ & $\begin{array}{l}-0.0022 \\
(0.0203)\end{array}$ & $\begin{array}{c}0.0039 \\
(0.0208)\end{array}$ & $\begin{array}{c}0.0024 \\
(0.0207)\end{array}$ & $\begin{array}{l}-0.0074 \\
(0.0196)\end{array}$ & $\begin{array}{l}-0.0132 \\
(0.0218)\end{array}$ \\
\hline In(Exchange)(-1) & $\begin{array}{l}-0.0004 \\
(0.0007)\end{array}$ & $\begin{array}{c}0.0000 \\
(0.0007)\end{array}$ & $\begin{array}{l}-0.0004 \\
(0.0007)\end{array}$ & $\begin{array}{l}-0.0004 \\
(0.0007)\end{array}$ & $\begin{array}{l}-0.0004 \\
(0.0008)\end{array}$ & $\begin{array}{l}-0.0004 \\
(0.0008)\end{array}$ & $\begin{array}{l}-0.0006 \\
(0.0008)\end{array}$ \\
\hline Diff_Government(-1) & & $\begin{array}{c}-0.0086^{* * * *} \\
(0.0022)\end{array}$ & & & & & \\
\hline Diff_Political(-1) & & & $\begin{array}{c}0.0022 \\
(0.0015)\end{array}$ & & & & \\
\hline Diff_Regulatory(-1) & & & & $\begin{array}{c}0.0029 \\
(0.0023)\end{array}$ & & & \\
\hline Diff_Law(-1) & & & & & & $\begin{array}{l}-0.0039 \\
(0.0025)\end{array}$ & \\
\hline Diff_Corruption(-1) & & & & & & & $\begin{array}{c}-0.0083 * * * \\
(0.0019)\end{array}$ \\
\hline constant & $\begin{array}{c}8.9979 * * * \\
(0.1888)\end{array}$ & $\begin{array}{c}8.9012 * * * \\
(0.2226)\end{array}$ & $\begin{array}{c}8.9772 * * * \\
(0.1957)\end{array}$ & $\begin{array}{c}8.9300 * * * \\
(0.2009)\end{array}$ & $\begin{array}{c}8.9447 * * * \\
(0.1978)\end{array}$ & $\begin{array}{c}9.0433 * * * \\
(0.1862)\end{array}$ & $\begin{array}{c}9.0810 * * * \\
(0.2115)\end{array}$ \\
\hline Year dummies & Yes & Yes & Yes & Yes & Yes & Yes & Yes \\
\hline Country dummies & Yes & Yes & Yes & Yes & Yes & Yes & Yes \\
\hline $\mathbf{N}$ & 1394 & 1382 & 1382 & 1382 & 1382 & 1382 & 1382 \\
\hline
\end{tabular}

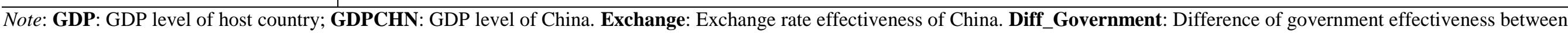

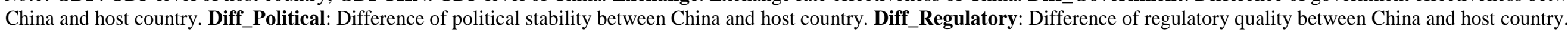

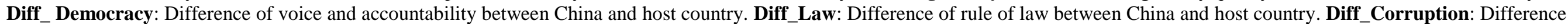

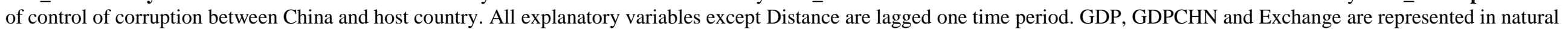

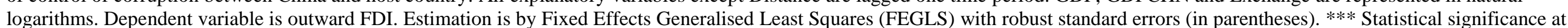
$1 \%$ level; ** Statistical significance at $5 \%$ level; * Statistical significance at $10 \%$ level. 
Table 6 Institutional difference and OFDI from China - FEGLS estimation with DID treatments

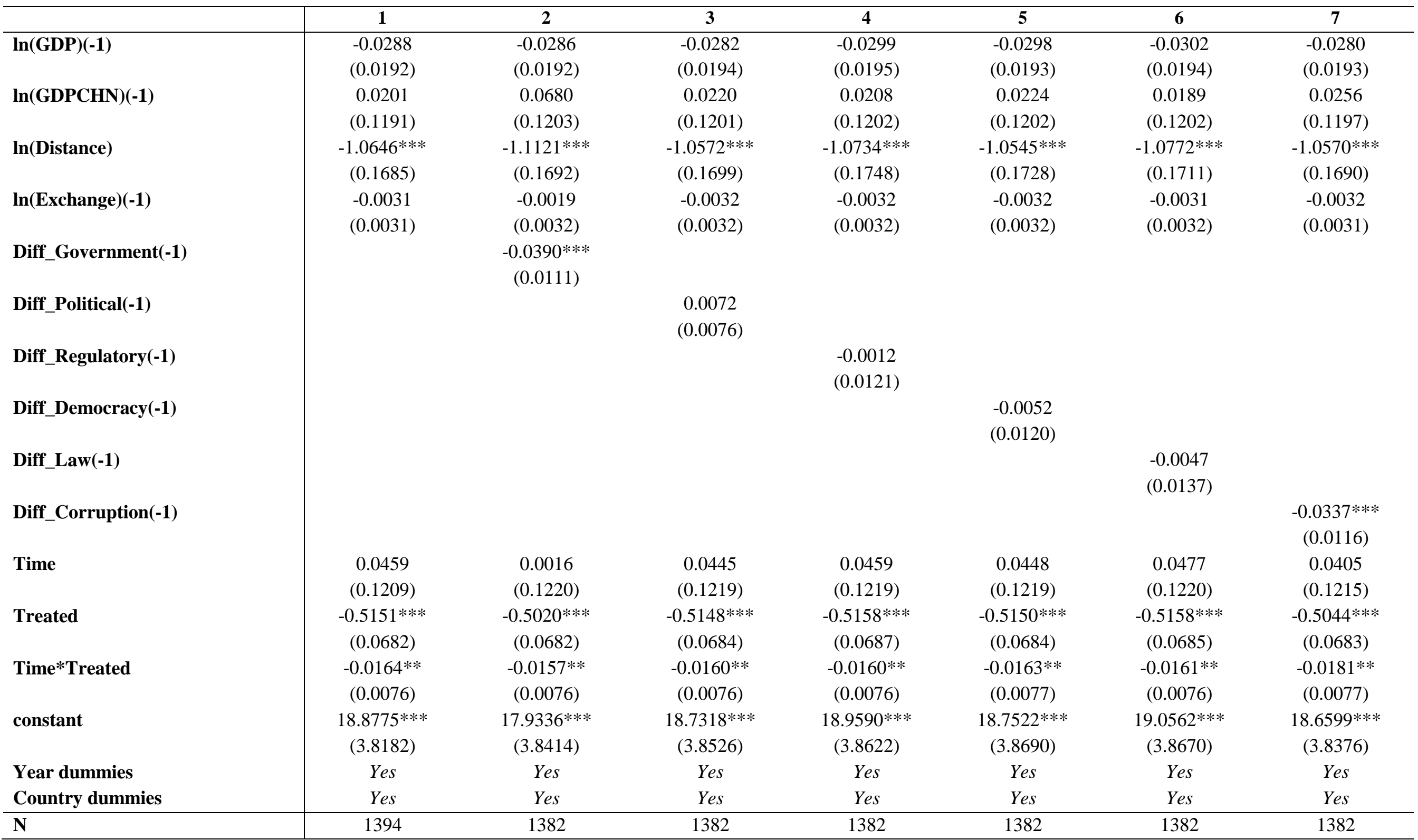

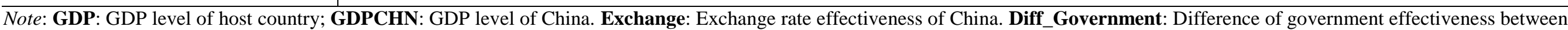

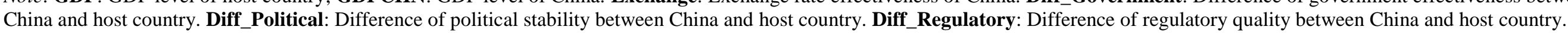




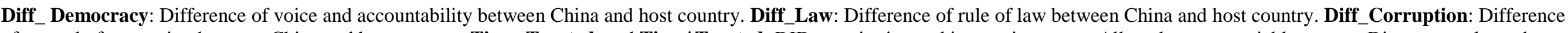

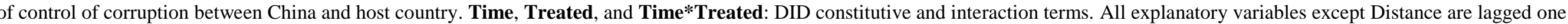

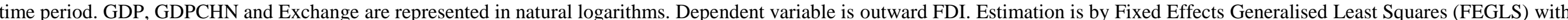
robust standard errors (in parentheses). *** Statistical significance at $1 \%$ level; ** Statistical significance at $5 \%$ level; * Statistical significance at $10 \%$ level. 
Table 7 Institutional difference and OFDI from China - FEGLS estimation with Hackman procedures

\begin{tabular}{|c|c|c|c|c|c|c|c|}
\hline & 1 & 2 & 3 & 4 & 5 & 6 & 7 \\
\hline $\ln ($ GDP)(-1) & $\begin{array}{c}0.0026 \\
(0.0033)\end{array}$ & $\begin{array}{c}0.0051 \\
(0.0035)\end{array}$ & $\begin{array}{c}0.0029 \\
(0.0034)\end{array}$ & $\begin{array}{c}0.0018 \\
(0.0033)\end{array}$ & $\begin{array}{c}0.0018 \\
(0.0033)\end{array}$ & $\begin{array}{c}0.0013 \\
(0.0033)\end{array}$ & $\begin{array}{c}0.0042 \\
(0.0037)\end{array}$ \\
\hline $\ln ($ GDPCHN)(-1) & $\begin{array}{c}0.0153 * \\
(0.0027)\end{array}$ & $\begin{array}{c}0.0150 * * \\
(0.0029)\end{array}$ & $\begin{array}{l}0.0160 * \\
(0.0028)\end{array}$ & $\begin{array}{l}0.0158 * \\
(0.0027)\end{array}$ & $\begin{array}{c}0.0163 * \\
(0.0028)\end{array}$ & $\begin{array}{c}0.0159 * \\
(0.0028)\end{array}$ & $\begin{array}{c}0.0152 * * \\
(0.0028)\end{array}$ \\
\hline In(Distance) & $\begin{array}{l}-0.0170 \\
(0.0193)\end{array}$ & $\begin{array}{l}-0.0157 \\
(0.0225)\end{array}$ & $\begin{array}{l}-0.0145 \\
(0.0196)\end{array}$ & $\begin{array}{l}-0.0150 \\
(0.0200)\end{array}$ & $\begin{array}{l}-0.0122 \\
(0.0202)\end{array}$ & $\begin{array}{l}-0.0263 \\
(0.0201)\end{array}$ & $\begin{array}{l}-0.0136 \\
(0.0214)\end{array}$ \\
\hline $\ln ($ Exchange $)(-1)$ & $\begin{array}{l}-0.0005 \\
(0.0008)\end{array}$ & $\begin{array}{l}-0.0004 \\
(0.0008)\end{array}$ & $\begin{array}{l}-0.0005 \\
(0.0008)\end{array}$ & $\begin{array}{l}-0.0003 \\
(0.0007)\end{array}$ & $\begin{array}{l}-0.0005 \\
(0.0008)\end{array}$ & $\begin{array}{l}-0.0006 \\
(0.0008)\end{array}$ & $\begin{array}{l}-0.0005 \\
(0.0008)\end{array}$ \\
\hline Diff_Government( & & $\begin{array}{c}- \\
(0.0022)\end{array}$ & & & & & \\
\hline Diff_Political(-1) & & & $\begin{array}{l}0.0019 * \\
(0.0011)\end{array}$ & & & & \\
\hline Diff_Regulatory(- & & & & $\begin{array}{l}0.0039 * \\
(0.0018)\end{array}$ & & & \\
\hline Diff_Democracy(- & & & & & $\begin{array}{c}-0.0033 * \\
(0.0020)\end{array}$ & & \\
\hline Diff_Law(-1) & & & & & & $\begin{array}{l}-0.0011 \\
(0.0023)\end{array}$ & \\
\hline Diff_Corruption(- & & & & & & & $\begin{array}{c}- \\
(0.0020)\end{array}$ \\
\hline Mills & $\begin{array}{l}0.0167 * \\
(0.0021)\end{array}$ & $\begin{array}{c}0.0160 * * \\
(0.0022)\end{array}$ & $\begin{array}{l}0.0166^{*} \\
(0.0020)\end{array}$ & $\begin{array}{l}0.0162 * \\
(0.0020)\end{array}$ & $\begin{array}{l}0.0169 * \\
(0.0021)\end{array}$ & $\begin{array}{l}0.0168 * \\
(0.0020)\end{array}$ & $\begin{array}{c}0.0188 * * \\
(0.0022)\end{array}$ \\
\hline constant & $\begin{array}{l}8.9798 * \\
(0.1842)\end{array}$ & $\begin{array}{c}8.9298 * * \\
(0.2093)\end{array}$ & $\begin{array}{l}8.9313 * \\
(0.1882)\end{array}$ & $\begin{array}{c}8.9616 * \\
(0.1898)\end{array}$ & $\begin{array}{l}8.9325^{*} \\
(0.1918)\end{array}$ & $\begin{array}{l}9.0731 * \\
(0.1895)\end{array}$ & $\begin{array}{c}8.9224 * * \\
(0.2070)\end{array}$ \\
\hline Year dummies & Yes & Yes & Yes & Yes & Yes & Yes & Yes \\
\hline Country dummies & Yes & Yes & Yes & Yes & Yes & Yes & Yes \\
\hline $\mathbf{N}$ & 1394 & 1382 & 1382 & 1382 & 1382 & 1382 & 1382 \\
\hline
\end{tabular}

Note: GDP: GDP level of host country; GDPCHN: GDP level of China. Exchange: Exchange rate effectiveness of China. Diff_Government: Difference of government effectiveness between China and host country. Diff_Political: Difference of political stability between China and host country. Diff_Regulatory: Difference of regulatory quality between China and host country. Diff_Democracy: Difference of voice and accountability between China and host country. Diff_Law: Difference of rule of law between China and host country. Diff_Corruption: Difference of control of corruption between China and host country. Mills: Mills ratio. All explanatory variables except Distance are lagged one time period. GDP, GDPCHN and Exchange are represented in natural logarithms. Dependent variable is outward FDI. Estimation is by Fixed Effects

Generalised Least Squares (FEGLS) with robust standard errors (in parentheses). *** Statistical significance at $1 \%$ level; ** Statistical significance at $5 \%$ level; * Statistical significance at $10 \%$ level. 